\title{
In vivo effects of recombinant human DNase I on sputum in patients with cystic fibrosis
}

\author{
Pallav L Shah, Sandra F Scott, Richard A Knight, Christopher Marriott, \\ Channa Ranasinha, Margaret E Hodson
}

\begin{abstract}
Background-Viscoelastic secretions in cystic fibrosis cause impaired mucus clearance and persistence of bacteria within the lung. The abnormal rheology is partly due to the presence of high molecular weight deoxyribonucleic acid (DNA). Recombinant human DNase I (rhDNase) has been shown to depolymerise DNA and thereby reduce the in vitro viscoelasticity of sputum in patients with cystic fibrosis. A phase II double blind placebo controlled study showed that rhDNase improved pulmonary function in patients with cystic fibrosis. The object of the present study was to evaluate the in vivo effects of rhDNase on sputum rheology and to determine whether these were correlated with changes in pulmonary function.
\end{abstract}

Methods-Patients were randomised to receive either placebo or rhDNase $2.5 \mathrm{mg}$ twice daily for 10 days. Sputum samples were collected in sterile containers during screening and during treatment with the study drug. Pulmonary function and rheological analysis were the primary outcomes evaluated. Other parameters assessed were quantitative sputum bacteriology, sputum DNA concentration, and change in molecular mass of DNA polymers.

Results - The viscoelasticity of the sputum in untreated patients with cystic fibrosis was high and treatment with rhDNase reduced all the rheological parameters measured: dynamic storage modulus (a measure of elasticity), dynamic loss modulus (a measure of viscosity), and log complex modulus (a measure of mucus rigidity). The calculated cough clearance index was also improved following treatment with rhDNase. These rheological parameters showed a correlation with forced expiratory volume in one second $\left(F_{E V}\right)_{1}$ which was improved by a mean (SE) of $13.3(5 \cdot 6) \%$ on day 10 of treatment with rhDNase compared with a change of $0.2(3 \cdot 1) \%$ in the placebo group. There was no change in bacterial colony counts or sputum DNA concentrations following treatment with rhDNase, but a small de- crease in high molecular weight DNA was observed.

Conclusions - Patients with cystic fibrosis treated with rhDNase show an improvement in rheological properties and pulmonary function, one of the mechanisms being a reduction in the proportion of high molecular weight DNA.

(Thorax 1996;51:119-125)

Keywords: cystic fibrosis, sputum, rhDNase, rheology, DNA content.

Progressive pulmonary disease is the major cause of morbidity and mortality in cystic fibrosis. ${ }^{12}$ Airways obstruction due to highly viscoelastic airway secretions in cystic fibrosis has usually been considered partially responsible for the pulmonary manifestations of the disease. Chronic obstruction is associated with impaired clearance and bacterial persistence, and this coexists with a neutrophil dominated host inflammatory response which is self perpetuating and ultimately leads to lung destruction. Disintegrating neutrophils release high concentrations of extracellular deoxyribonucleic acid (DNA) ${ }^{3}$ which have been found in purulent sputum in patients with cystic fibrosis at concentrations of $3-14 \mathrm{mg} / \mathrm{ml} .{ }^{45}$ The complexes formed between polymerised DNA strands and mucus glycoproteins contribute to the increased viscoelasticity of purulent secretions in cystic fibrosis.

The high viscoelasticity of sputum in patients with cystic fibrosis impairs both cough clearance and mucociliary transport ${ }^{7}$ and its reduction may therefore have beneficial effects by improving clearance of airway secretions. The value of mucolytic agents which are directed at the mucus glycoproteins has been controversial, and they are now not routinely used in the management of cystic fibrosis. ${ }^{8}$ For example, aerosol therapy with $\mathrm{N}$-acetylcysteine is associated with irritation of the airways and bronchospasm, and controlled studies with oral preparations have demonstrated no consistent benefits. ${ }^{9-11}$

Recombinant human DNase I (rhDNase) has been shown to depolymerise DNA and reduce sputum viscosity in vitro. ${ }^{12}$ The phase I studies showed that the drug was safe in both 
normal adults and patients with cystic fibrosis, and that it improved pulmonary function in the latter group. ${ }^{1314} \mathrm{~A}$ multicentre double blind placebo controlled short term study performed in the USA showed significant improvements in pulmonary function in patients who received rhDNase. ${ }^{15}$ Forced expiratory volume in one second $\left(\mathrm{FEV}_{1}\right)$ was improved by $10-15 \%$ over the 10 day treatment period. A phase II double blind placebo controlled study conducted at our centre produced similar results. ${ }^{16}$ A phase III double blind placebo controlled study was conducted in over 50 centres in North America in which 968 patients with cystic fibrosis were randomised to receive either placebo, rhDNase $2.5 \mathrm{mg}$ once daily, or $2.5 \mathrm{mg}$ twice daily for six months. ${ }^{17} \mathrm{~A}$ modest reduction in the risk of exacerbations of respiratory symptoms requiring parenteral antibiotics was observed (reduction by $22 \%$ and $34 \%$ in the rhDNase once daily and twice daily groups, respectively). Pulmonary function was also improved by about $6 \%$ over the six month treatment period.

The objective of the present study was to evaluate the effects of rhDNase on sputum rheology in vivo and to determine whether any changes produced were associated statistically with improvements in pulmonary function.

\section{Methods}

STUDY DESIGN

A phase II short term double blind placebo controlled study was conducted in the UK. ${ }^{16}$ Seventy one patients with cystic fibrosis older than 15 years of age with a forced vital capacity (FVC) of $>40 \%$ predicted were randomised to receive either rhDNase $2.5 \mathrm{mg}$ twice daily or placebo $(150 \mathrm{mmol} \mathrm{NaCl}, 1.5 \mathrm{mmol} \mathrm{CaCl}$ ) for a period of 10 days followed by a 32 day follow up period. The study drug was delivered using a Pulmo-Aide compressor (DeVilbiss, Somerset, Pennsylvania, USA) in conjunction with an Acorn II jet nebuliser (Marquest, Englewood, Colorado, USA).

The patients were required to have documented evidence of cystic fibrosis either by a sweat sodium concentration of $>70 \mathrm{mmol} / \mathrm{l}$ by quantitative pilocarpine iontophoresis ${ }^{18}$ or to be homozygous for the $\Delta \mathrm{F} 508$ marker on genetic testing with a clinical history indicative of cystic fibrosis. The condition of the patients was stable for at least 14 days before the study and there were no changes in concomitant medications including oral steroids, antibiotics, or bronchodilators.

Sputum samples were collected five days before treatment, on the last day of treatment with the study drug (day 10), and on day 42 of the study (when off placebo or rhDNase for 32 days). All the data refer to samples collected at these times from patients in the rhDNase and placebo arms of the study. The sputum was collected over a two hour period at the same time of day (for day 10 approximately 12-16 hours following their last dose of study drug). The samples were stored at $-20^{\circ} \mathrm{C}$ until analysed.

Pulmonary function tests were performed at each study visit using a Microlab 3000 series spirometer (Vitalograph, Buckingham, UK) according to the American Thoracic Society guidelines. ${ }^{19}$ Intrapatient variability was minimised by reviewing patients at the same time of day throughout the study and reproducibility assessed before commencing the study drug. Pulmonary function results were standardised according to age, sex, and height using Knudson tables. ${ }^{20}$

\section{RHEOLOGICAL ANALYSIS OF SPUTUM \\ Principles}

The elastic solid is an energy storing device. When a force is applied there is displacement of the structure and energy is stored within it. The energy is released and the structure reverts to its original state when the force is removed. Therefore, the higher the elasticity or dynamic storage modulus $\left(\mathrm{G}^{\prime}\right)$ of a substance the greater the amount of energy that can be stored within it for a given degree of displacement which implies a highly developed interlinked structure. Viscosity is that element of a substance that resists flow when a force is applied to it. There is no energy storage and any applied force is dissipated as heat. The higher the viscosity or dynamic loss modulus $\left(\mathrm{G}^{\prime \prime}\right)$ of a substance the greater the force required to create a given degree of displacement which implies a more "solid structure", whereas a low viscosity suggests a more "liquid structure". The mucus rigidity factor or dynamic complex modulus $\left(\mathrm{G}^{*}\right)$ is a measure of both elasticity and viscosity and represents the overall stress to strain ratio in a dynamic experiment. A high complex modulus implies a very rigid structure. The viscoelasticity derived cough clearance index (CCI) was also calculated from in vitro relationships derived from model studies of clearance ${ }^{2122}$ using $G^{*}, G^{\prime}$, and $G^{\prime \prime}$ measured at an angular frequency of $15 \cdot 8 \mathrm{~Hz}\left(100 \mathrm{rad}^{-1}\right)$. The formula used was:

$\tan \delta_{100}=\mathrm{G}^{\prime \prime}{ }_{100} / \mathrm{G}^{\prime}{ }_{100}$

$$
\mathrm{CCI}=3.44-\left(1.07 \times \log \mathrm{G}^{*}{ }_{100}+0.89 \times \tan \delta_{100}\right)
$$

Dynamic oscillatory analysis was utilised for the rheological analysis and is based on the principle that, if a sinusoidally varying stress wave is applied, an output sinusoidal strain wave will be transmitted by the sample in the linear viscoelastic range of the substance. The amplitude ratio and phase lag between the two displacement waveforms allows the various rheological parameters to be calculated. This technique causes minimum perturbation of the test material and allows the structure to be evaluated in its ground state. The technique can analyse structural elements with relatively fast response times and, since the dynamic test involves exposing the substance to a range of frequencies, a complete spectrum of behaviour can be obtained.

\section{Methods}

The rheological analysis was performed in a blind manner. The sputum samples were al- 
Table 1 Mean (SE) pulmonary function in the placebo and rhDNase groups

\begin{tabular}{lllll}
\hline & $F E V_{1}(l)$ & $F V C(l)$ & $\%$ change in FEV & \% change in FVC \\
\hline $\begin{array}{llll}\text { Placebo (n=21) } \\
\quad \text { Before treatment }\end{array}$ & $1.44(0.13)$ & $2.75(0.21)$ & & \\
After treatment & $1.46(0.17)$ & $2.86(0.25)$ & $0.15(3.08)$ & $3.26(3.99)$ \\
rhDNase $(\mathrm{n}=20)$ & & & & \\
$\quad$ Before treatment & $1.58(0.2)$ & $3.25(0.29)$ & & \\
After treatment & $1.78(0.2)$ & $3.43(0.29)$ & $13.32(5.57)^{*}$ & $8.22(5.64) \dagger$ \\
\hline${ }^{*} \mathrm{p}<0.05 ; \dagger \mathrm{p}=\mathrm{NS}$. & & & &
\end{tabular}

lowed to thaw at room temperature before rheological analysis. The thawed samples were left for 30 minutes at $20^{\circ} \mathrm{C}$ to allow recovery of the gel structure induced by the freezing process. The time interval and temperature was carefully controlled to minimise proteolysis. Preliminary experiments demonstrated that protease activity significantly increases after standing for more than six hours at room temperature. Any samples that were contaminated with blood or had undergone syneresis were discarded. The CSL 100 rheometer (TA Instruments, UK) was used in dynamic oscillatory mode using parallel plate geometry. The rheometer consists of a minimum friction low inertia air bearing system which supports an upper parallel plate and allows a computer generated stress wave to be applied using an induction motor. The displacement geometry of the test substance is detected by an optical encoder and the temperature within the system is controlled by a Peltier system. A $4 \mathrm{~cm}$ diameter parallel plate with a gap set at $250 \mu \mathrm{m}$ was used. The sputum sample was placed in between the parallel plates, care was taken to exclude air bubbles, and excess sputum adhering to the edge of the plate was removed. A frequency sweep was conducted from $0.2 \mathrm{~Hz}$ to $20 \mathrm{~Hz}$ at $20^{\circ} \mathrm{C}$. The dynamic storage modulus $\left(\mathrm{G}^{\prime}\right.$, a measure of elasticity), the dynamic loss modulus ( $G^{\prime \prime}$, a measure of viscosity), and the complex modulus $\left(\mathrm{G}^{*}\right.$, a measure of mucus rigidity) were measured.

\section{SPUTUM BACTERIOLOGY}

Fresh sputum samples collected on days -5 and 10 were sent for quantitative bacteriology.

DNA ANALYSIS (TOTAL DNA CONCENTRATION AND MOLECULAR MASS OF DNA FRAGMENTS) Sputum samples from 12 patients (six placebo and six rhDNase group) before and 10 days after treatment were selected at random for DNA analysis. Sputum DNA was solubilised by incubation with $0.5 \%$ sodium dodecyl sulphate and proteinase $\mathrm{K}(100 \mu \mathrm{g} / \mathrm{ml})$ in the presence of $5 \mathrm{mmol}$ EDTA. This was followed by two extractions with phenol/chloroform and precipitation with absolute ethanol. The DNA was resolubilised in $10 \mathrm{mmol}$ Tris/1 mmol EDTA buffer at $\mathrm{pH}$ 8. DNA concentration was measured by ultraviolet spectrophotometry at a wavelength of $260 \mathrm{~nm}$. Electrophoresis was performed on $1.2 \%$ agarose gels using ethidium bromide to label the DNA and the relative quantity (RQ) within four molecular mass ranges $(12 \mathrm{~kb}$ to $2 \mathrm{~kb}, 2 \mathrm{~kb}$ to $750 \mathrm{~b}, 750 \mathrm{~b}$ to $150 \mathrm{~b}$, and $<150 \mathrm{~b}$ ) evaluated by an optical analyser (Quantity One, Discovery Series PDI). A lambda Hind III digest DNA ladder (Sigma, Poole, Dorset, UK) was used as a marker for molecular weight.

\section{STATISTICAL ANALYSIS}

Due to variation in the rheological properties of sputum between patients, the statistical analysis was based on comparison between samples obtained from the same patient before and during treatment. Analysis was therefore limited to patients where suitable samples were obtained at each study point (day -5 , day 10 , and day 42).

The data were tested for normality and significant deviations were found and therefore the results are presented as medians with interquartile ranges. Significance between the rhDNase and placebo groups was calculated using a Mann-Whitney U test on the change from pretreatment (day -5) and treatment (day 10) samples. The data on pulmonary function are presented as mean (SE) and evaluated as mean percentage change from baseline as previously reported. ${ }^{16}$ Pulmonary function results were converted to percentage predicted values depending on age, sex, and height using Knudson tables ${ }^{20}$ for the purpose of correlation with rheology and evaluated using Spearman's correlation coefficients.

\section{Results}

PULMONARY FUNCTION

Complete samples (both before and during treatment) suitable for analysis were obtained from 41 patients, 21 in the placebo group and 20 in the rhDNase group. There was no significant difference in baseline pulmonary function between the two groups (table 1). The mean (SE) percentage increase from baseline in $\mathrm{FEV}_{1}$ in this group of patients on day 10 of the study was $13.3(5.5) \%$ in the rhDNase treated group compared with $0 \cdot 2(3 \cdot 1) \%$ in the placebo group $(\mathrm{p}<0 \cdot 05) . \mathrm{FEV}_{1}$ had returned to baseline by day 42 of the study. FVC was not significantly altered by day 10 of treatment with rhDNase. The baseline characteristics of this 41 patient cohort were similar to those for the overall population of 71 patients. Changes in lung function in the placebo and rhDNase groups of this cohort were similar to those observed following treatment with the study drug in the overall population and in those 30 patients excluded from analysis in the current study. The change in $\mathrm{FEV}_{1}$ for the total population was $+13 \cdot 3 \%$ in the rhDNase treatment arm and $-0 \cdot 2 \%$ in the placebo group.

\section{SPUTUM RHEOLOGY}

The viscoelasticity of sputum in patients with cystic fibrosis before treatment was high: the median dynamic storage modulus $\left(G^{\prime}\right)$ was $34 \cdot 3(14 \cdot 4-79 \cdot 3) \mathrm{N} \mathrm{m}^{-2}$, median dynamic loss modulus $\left(G^{\prime \prime}\right)$ was $13 \cdot 0(4 \cdot 2-24 \cdot 8) \mathrm{N} \mathrm{m}^{-2}$, and the median $\log$ complex modulus (log $G^{*}$ ) was $1.67(1 \cdot 28-1 \cdot 96)$. Sputum rheology was 

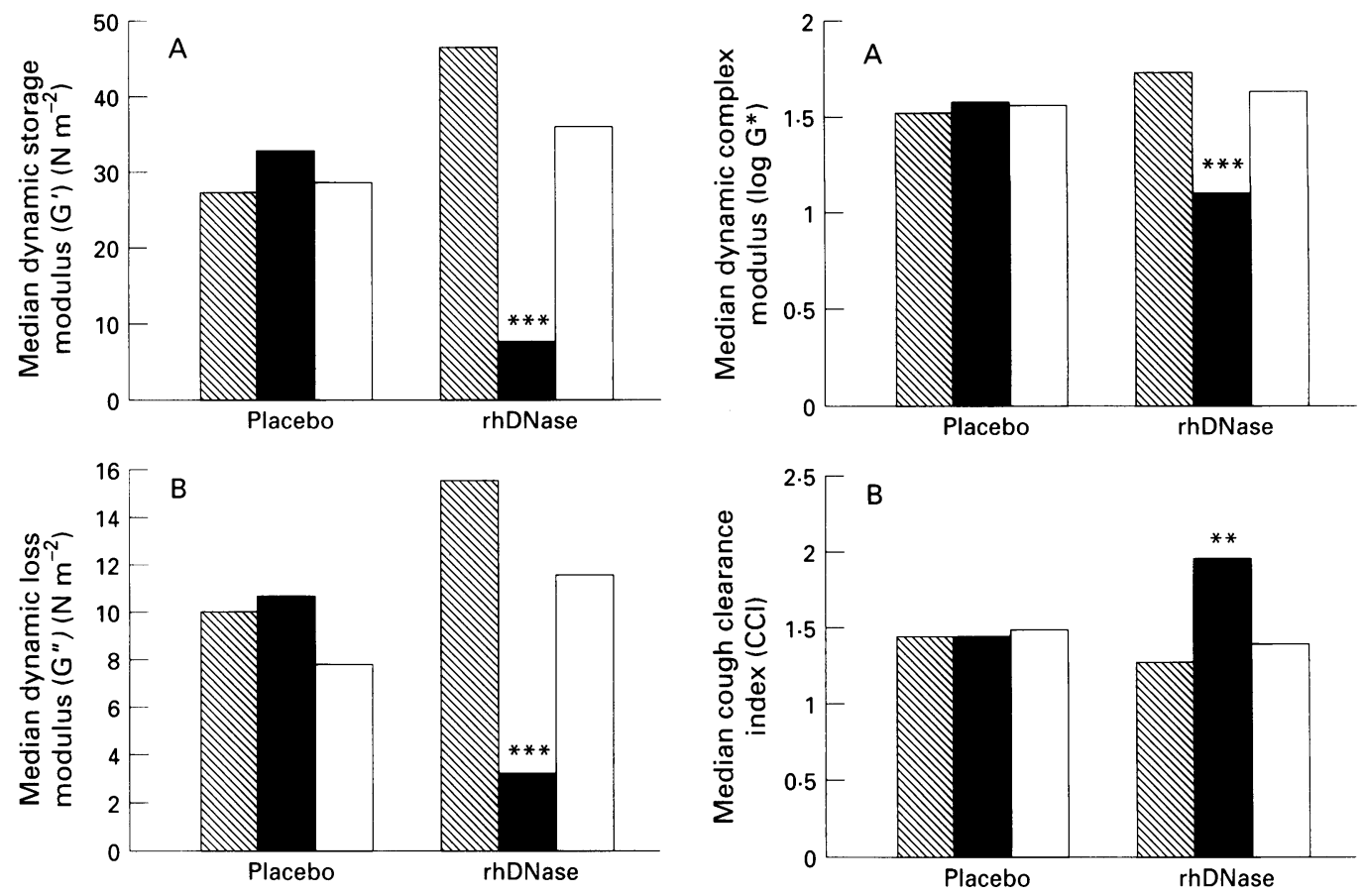

Figure 1 Median changes in $(A)$ sputum elasticity $\left(G^{\prime}\right)$ and $(B)$ sputum viscosity $\left(G^{\prime \prime}\right)$ for the placebo and rhDNase groups. $\mathbb{N}$, before treatment (day -5$)$; treatment (day 10); $\square$, after treatment (day 42). $* * * p<0.001$.

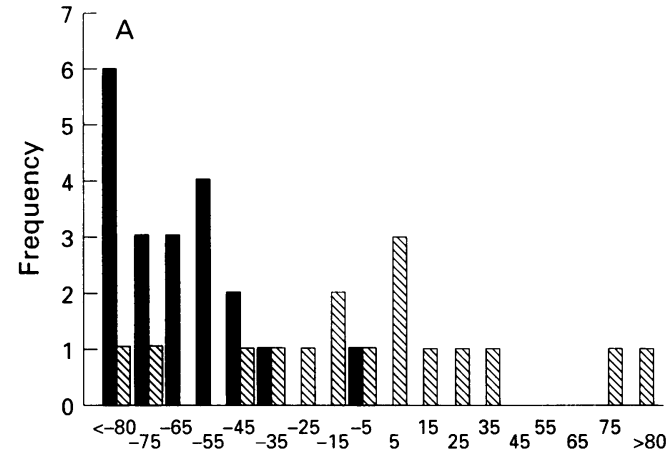

Figure 3 Median changes in (A) mucus rigidity factor $\left(G^{*}\right)$ and $(B)$ cough clearance index $(C C I)$ for the placebo and rhDNase groups. $\mathbb{N}$, before treatment (day -5), $\square$, treatment (day 10), $\square$, after treatment (day 42). $* * * p<0.001, * * p<0.005$

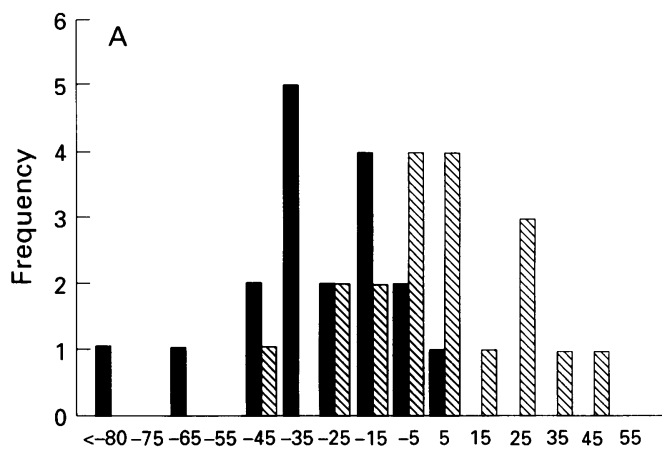

$\%$ change in sputum elasticity

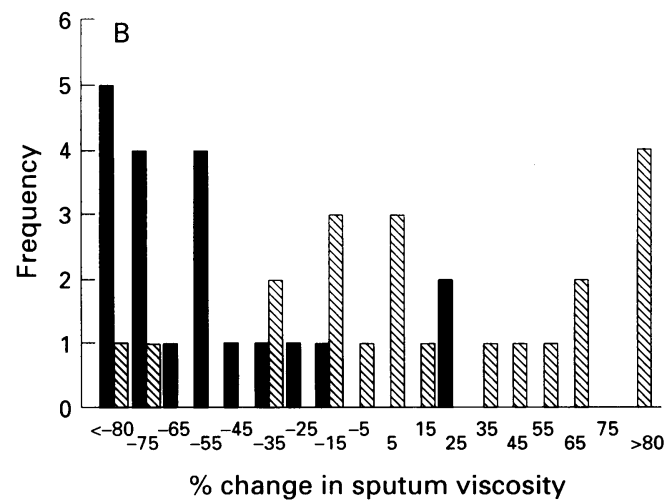

Figure 2 Histogram of $(A)$ percentage change in sputum elasticity $\left(G^{\prime}\right)$ and $(B)$ percentage change in sputum viscosity $\left(G^{\prime \prime}\right)$ following 10 days of treatment with either placebo or rhDNase

unchanged following treatment with placebo whereas significant reductions in all rheological parameters were observed following treatment with rhDNase (figs 1-4). The results for $\mathrm{G}^{\prime}$ and $\mathrm{G}^{\prime \prime}$ are presented at $9.5 \mathrm{~Hz}$ as this approximates to ciliary beat frequency. There was

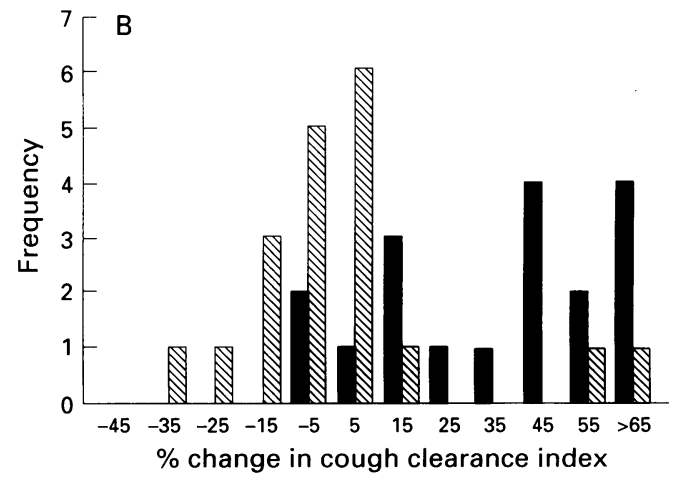

Figure 4 Histogram of $(A)$ percentage change in sputum rigidity $\left(\log G^{*}\right)$ and $(B)$ percentage change in cough clearance (CCI) following 10 days of treatment with either placebo or rhDNase $\mathbf{\square}$.

a median reduction of $27 \cdot 7(7 \cdot 4-91 \cdot 9) \mathrm{N} \mathrm{m}^{-2}$ in sputum elasticity $\left(\mathrm{G}^{\prime}\right)$ following treatment with rhDNase $(\mathrm{p}<0.001$ compared with placebo). The histogram showing the percentage change in elasticity in the two groups (fig $2 \mathrm{~A}$ ) emphasises the considerable variation and 
Table 2 Median (interquartile range) relative quantity of DNA within specific molecular weight ranges, DNA concentration, and DNA ratio for placebo and rhDNase groups

\begin{tabular}{|c|c|c|c|c|c|c|}
\hline & $\begin{array}{l}\text { (A) } \\
12 \mathrm{~kb} \text { to } 2 \mathrm{~kb}\end{array}$ & $\begin{array}{l}\text { (B) } \\
2 \mathrm{~kb} \text { to } 750 \mathrm{~b}\end{array}$ & $\begin{array}{l}(C) \\
750 b \text { to } 150 b\end{array}$ & $\begin{array}{l}\text { (D) } \\
<150 b\end{array}$ & $\begin{array}{l}D N A \\
\text { ratio }(D / A)\end{array}$ & $\begin{array}{l}\text { DNA } \\
\text { concentration } \\
\text { (mg/ml) }\end{array}$ \\
\hline \multicolumn{7}{|l|}{ Placebo } \\
\hline $\begin{array}{l}\text { Before treatment } \\
\text { After treatment }\end{array}$ & $\begin{array}{l}19 \cdot 80(16 \cdot 63-28 \cdot 53) \\
25 \cdot 85(18 \cdot 05-27 \cdot 78)\end{array}$ & $\begin{array}{l}21.35(20 \cdot 15-21 \cdot 85) \\
21.95(19 \cdot 88-22 \cdot 85)\end{array}$ & $\begin{array}{l}25 \cdot 80(24 \cdot 30-29 \cdot 83) \\
23 \cdot 70(22 \cdot 98-26 \cdot 38)\end{array}$ & $\begin{array}{l}25 \cdot 55(21 \cdot 50-30 \cdot 78) \\
25 \cdot 30(24 \cdot 38-30 \cdot 2)\end{array}$ & $\begin{array}{ll}1.24 & (0.80-1.87) \\
0.92 & (0.90-1.68)\end{array}$ & $\begin{array}{l}2.48(1.36-3.43) \\
2.63(1.99-4.14)\end{array}$ \\
\hline \multicolumn{7}{|l|}{ rhDNase } \\
\hline $\begin{array}{l}\text { Before treatment } \\
\text { After treatment }\end{array}$ & $\begin{array}{l}20 \cdot 20(16 \cdot 4-24 \cdot 85) \\
18.05(16 \cdot 48-18 \cdot 85)\end{array}$ & $\begin{array}{l}21.65(21.00-22.53) \\
18.50(17.63-20.83)\end{array}$ & $\begin{array}{l}26.00(23.68-30.73) \\
24.80(21.58-30.73)\end{array}$ & $\begin{array}{l}25 \cdot 25(20 \cdot 78-29 \cdot 30) \\
31 \cdot 06(28 \cdot 15-35 \cdot 15)\end{array}$ & $\begin{array}{l}1.28(0.86-1 \cdot 79) \\
1.83 *(1.44-2 \cdot 07)\end{array}$ & $\begin{array}{l}1.90(0.99-3.94) \\
2.10(1.65-2.79)\end{array}$ \\
\hline
\end{tabular}

$* \mathrm{p}<0.05$.

heterogeneity in rheological properties of sputum. Two patients who received placebo had increases in $\mathrm{G}^{\prime}$ of $>70 \%$ compared with two who had a decrease in $\mathrm{G}^{\prime}$ of $>70 \%$. There was a decline in $G^{\prime}$ in all patients treated with rhDNase and the median decrease was $67 \cdot 7 \%$ (fig $2 A$ ). Viscosity $\left(G^{\prime \prime}\right)$ was reduced by $59.0 \%$ in the rhDNase group and this represented a median reduction of $10.8(1 \cdot 8-20 \cdot 2) \mathrm{N} \mathrm{m}^{-2}$ in comparison with a median increase of 1.2 $(-2 \cdot 0-3 \cdot 8)$ in the placebo group $(\mathrm{p}<0.001)$. All but two patients who were treated with rhDNase demonstrated a decline in sputum viscosity at day 10 (fig $2 \mathrm{~B}$ ). The results for $\mathrm{G}^{\prime}$ and $G^{\prime \prime}$ measured over the frequency range $0 \cdot 2-20 \mathrm{~Hz}$ were improved in a similar manner.

The dynamic complex modulus or mucus rigidity factor $\left(\log \mathrm{G}^{*}\right)$ at an angular frequency of $15.8 \mathrm{~Hz}$ was also significantly reduced following treatment with rhDNase $(p<0.001$, fig $3 \mathrm{~A})$. The change of $0.44 \mathrm{log}$ units in $\mathrm{G}^{*}$ represented a $30 \%$ reduction (fig $4 \mathrm{~A}$ ). The changes in sputum viscoelasticity are associated with an improvement in the cough clearance index (CCI). This index is derived from the viscoelastic parameters at an angular frequency of $15.8 \mathrm{~Hz}$ and predicts cough clearability. The CCI was $1.27(0.95-1.83)$ for the rhDNase group before treatment (fig 3B). This index was significantly improved to $1.95(1.36-2.08)$ following treatment with rhDNase $(\mathrm{p}<0.001)$. Two patients treated with rhDNase demonstrated a decline in the CCI (fig 4B).

CORRELATION BETWEEN SPUTUM RHEOLOGY AND PULMONARY FUNCTION

At baseline there was a statistically significant correlation between percentage predicted $\mathrm{FEV}_{1}$ and all the rheological parameters for both treatment groups: elasticity $(-0.43, \mathrm{p}<0.005)$, viscosity $(-0.43, \mathrm{p}<0.005)$ and mucus rigidity $(-0.38, p<0.05)$. The relationships were maintained on day 10 during treatment with the study drug and on day 42 (one month after treatment) for all rheological parameters except for viscosity at treatment day 10 . The correlations between percentage change in rheological parameters and change in percentage predicted $F E V_{1}$ for the rhDNase group were: elasticity $(-0.29, \mathrm{NS})$, viscosity $(-0.32$, $\mathrm{p}<0.05)$, and mucus rigidity $(-0.35, \mathrm{p}<0.05)$. A correlation between percentage predicted FVC and rheological parameters $(p<0.05)$ existed at baseline, and between the $\mathrm{FEV}_{1} / \mathrm{FVC}$ ratio and the rheological parameters $(p<0.05)$. However, these weak correlations were not maintained on treatment day 10 or day 42 . A statistically significant $(\mathrm{p}<0.05)$ correlation also existed between CCI and percentage predicted $\mathrm{FEV}_{1}$ at all the time points evaluated. There was also a correlation between percentage change in CCI and change in percentage predicted $\mathrm{FEV}_{1}$ for the rhDNase group $(0.42, \mathrm{p}<0.02)$. Both rheological parameters and cough clearance were improved in all but two patients who were treated with rhDNase. The change in $\mathrm{FEV}_{1}$ in these two individuals was $+4 \cdot 2 \%$ and $+10 \cdot 9 \%$, respectively. FEV failed to improve in five patients who received rhDNase despite reasonable decreases in rheological properties of the sputum.

SPUTUM BACTERIOLOGY

Mucoid Pseudomonas aeruginosa was cultured in $58.5 \%$ of patients and median colony counts were $1 \times 10^{7}$ colony forming units $(\mathrm{cfu}) / \mathrm{ml}$. Non-mucoid $P$ aeruginosa was present in $48.8 \%$ of patients (median colony counts were $1 \times 10^{7} \mathrm{cfu} / \mathrm{ml}$ ), Staphylococcus aureus was present in $34.2 \%$ (median colony counts of $1 \times 10^{6}$ $\mathrm{cfu} / \mathrm{ml}$ ) and Burkholderia cepacia in $9.8 \%$ (median colony counts of $1 \times 10^{6} \mathrm{cfu} / \mathrm{ml}$ ). More than one organism was detected in the sputum of some of these patients. There was no significant change in sputum bacteriology before and after treatment with rhDNase. Changes in rheological parameters were not influenced by colonisation with mucoid $P$ aeruginosa.

DNA ANALYSIS (TOTAL DNA CONCENTRATION AND MOLECULAR MASS OF DNA FRAGMENTS) The concentration of DNA in the sputum was similar in the placebo and rhDNase groups and was unchanged following 10 days of treatment with rhDNase in vivo (table 2 ). The agarose gel electrophoretograms demonstrate a reduction in the RQ of high molecular mass DNA and a corresponding increase in low molecular mass DNA polymers following in vivo treatment with rhDNase (table 2). This represented a decrease of $10.7 \%$ in the $12 \mathrm{~kb}$ to $2 \mathrm{~kb}$ molecular mass range, $14.5 \%$ in the $2 \mathrm{~kb}$ to $750 \mathrm{~b}$ range, and a median increase of $25 \cdot 7 \%$ in the low molecular mass range $(<150 \mathrm{~b})$. A ratio of the RQ of low molecular mass $(<150 \mathrm{~b}$ ) DNA and high molecular mass ( $12 \mathrm{~kb}$ to $2 \mathrm{~kb}$ ) DNA was calculated in order to evaluate the shift in DNA fragment size. The ratio was not significantly altered in the placebo group (from 1.27 to 0.92 ), although a significant increase was seen following treatment with rhDNase 
(from 1.28 to $1.83, \mathrm{p}<0.05$ ). There was a correlation between the percentage change in large molecular weight DNA and the change in percentage predicted $\mathrm{FEV}_{1}(-0.6, \mathrm{p}<0.05)$ and between the change in DNA ratio and the change in rheology $(-0.71, \mathrm{p}<0.05)$. However, in the small number of patients who had sputum DNA analysis there was no overall correlation between change in DNA size, change in rheological parameters, and change in pulmonary function.

\section{Discussion}

The improvement of $13.3 \%$ in $\mathrm{FEV}_{1}$ following treatment with rhDNase in the cohort studied was similar to changes in $\mathrm{FEV}_{1}$ in the patients who received rhDNase but were not included in the analysis due to inadequate sputum samples. The results following 10 days of treatment with $2.5 \mathrm{mg}$ rhDNase are similar to those reported for the overall population $(13 \cdot 3 \%)^{16}$ and those observed in the US phase II study $(13.8 \%){ }^{15}$

Treatment with rhDNase of patients with cystic fibrosis resulted in a reduction in sputum viscoelasticity with improvements in pulmonary function. The greatest change occurred in sputum elasticity $\left(\mathrm{G}^{\prime}\right)$ with a median reduction of around $68 \%$ whilst a smaller change, of the order of $30 \%$, was seen for the mucus rigidity factor $\left(\log \mathrm{G}^{*}\right)$. Reduction in the rheological parameters may reduce the amount of energy required to fragment the abnormally rigid mucus plug and improve clearance by propulsive expiratory airflows generated by coughing or forced expiratory techniques of physiotherapy. A decrease in the intraluminal secretions will probably be reflected in an improvement in pulmonary function, especially $\mathrm{FEV}_{1}$ and the $\mathrm{FEV}_{1} / \mathrm{FVC}$ ratio. FVC may be improved due to a reduction in mucus plugging. Radioaerosol imaging has shown a trend towards increased homogeneity of aerosol distribution following rhDNase treatment in patients with cystic fibrosis, suggesting that a reduction in intraluminal secretions obstructing the airways does indeed occur. ${ }^{23}$

Evaluation of the impact of rheology on mucociliary clearance is difficult in cystic fibrosis due to the role of the other factors such as bacterial toxins, neutrophil elastase, abnormalities in the electrolyte concentration of periciliary fluid, and adequacy of ciliary function. The improvements in the rheological parameters are likely to improve mucociliary clearance and the radioaerosol study also suggested that the rate of clearance from the inner zone of the lung was improved following treatment with rhDNase. Ex vivo studies of mucus transport on the frog palate model have shown that there is a rheological optimum for transport. ${ }^{24-27}$ At low values of elasticity $\left(0-5 \mathrm{~N} \mathrm{~m}^{-2}\right)$ mucus is transported at a low rate. Transport rates increased when mucus elasticity was between 5 and $10 \mathrm{~N} \mathrm{~m}^{-2}$, but further increases in elasticity caused a decrease in transport rates. Overliquefaction of sputum could therefore impair its actual transportability. In one patient sputum elasticity was reduced to the $0-5 \mathrm{~N} \mathrm{~m}^{-2}$ range and this may explain why his $\mathrm{FEV}_{1}$ was only improved by $4 \%$ in comparison with the mean improvement of $13 \%$. Treatment with rhDNase resulted in a reduction in the viscoelasticity of sputum in patients with cystic fibrosis to below values observed for sputum from non-cystic fibrosis patients with bronchiectasis $\left(\mathrm{G}^{\prime} \approx 21.9 \mathrm{~N} \mathrm{~m}^{-2}, \mathrm{G}^{\prime \prime} \approx 6.1 \mathrm{~N} \mathrm{~m}^{-2}\right){ }^{28}$

The statistical correlation between sputum viscoelasticity and pulmonary function is weak and many other factors undoubtedly are involved. The quantity and location of intraluminal secretions vary from patient to patient and may influence the magnitude of the change in pulmonary function. Cough is a vital mechanism for the clearance of secretions in cystic fibrosis and this clearance may be affected by factors other than mucus rheology such as airway calibre, patient wellbeing, and nutritional status. Surface properties of mucus such as adhesion may also influence the clearance of secretions.

The in vivo results demonstrate only a $10 \%$ reduction in large molecular weight DNA $(12 \mathrm{~kb}$ to $2 \mathrm{~kb}$ ) and a $25 \%$ increase in low molecular weight DNA following treatment with rhDNase. The large interquartile ranges in all the molecular weight groups for both the placebo and rhDNase treatment groups indicate the considerable heterogeneity of sputum from patients with cystic fibrosis (table 2). Although the effect on DNA polymers of more than $12 \mathrm{~kb}$ have not been evaluated, there is a significant increase in the ratio of low to high molecular weight DNA in the rhDNase treatment group. It is unlikely that DNA hydrolysis is the sole mode of action of rhDNase. Actin released by degenerating neutrophils is found in the sputum of patients with cystic fibrosis in concentrations of 0.1 to $5 \mathrm{mg} / \mathrm{ml}$ and forms polymers which are highly viscoelastic. ${ }^{29}$ Deoxyribonuclease causes depolymerisation of filamentous muscle actin with a concomitant reduction in the viscosity of the filamentous actin/deoxyribonuclease mixture. ${ }^{30}$ The monomeric actin forms stable 1:1 complexes with deoxyribonuclease which limit its DNA hydrolysing activity. ${ }^{3031}$ Depolymerisation of filamentous actin by rhDNase is a kinetically inefficient process but may contribute to the reduction in viscoelasticity and merits further investigation. Alternatively, the rather small changes in DNA polymer size may be due to inhibition of the DNA hydrolysing activity of rhDNase by actin in the sputum of cystic fibrosis patients. Treatment with rhDNase results in the liberation of cationic proteases that were previously electrostatically bound to anionic DNA polymers. ${ }^{32}$ Proteolysis may also contribute to the reduction in viscoelasticity observed.

It would appear likely that the beneficial effects of rhDNase, both in terms of improvement in rheological parameters and lung function, may be due to the degradation of high molecular weight DNA in vivo.

The authors thank Mr S Ingham for technical advice and assistance, the microbiology department (Royal Brompton Hospital) for performing quantitative bacteriology on the sputum pital) for performing quantitative bacteriology on the sputum
samples, Mrs J Turner (medical statistician) for statistical advice, and Genentech Inc for supplying the rhDNase. 
1 Penketh AR, Wise A, Mearns MB, Hodson ME, Batten JC. Cystic fibrosis in adolescents and adults. Thorax 1987;42: 526-32.

2 FitzSimmons SC. The changing epidemiology of cystic fibrosis. F Pediatr 1993;122:1-9.

3 Lethem MI, James SL, Marriott C, Burke JF. The origin of DNA associated with mucus glycoproteins in cystic fibrosis sputum. Eur Respir f 1990;3:19-23.

4 Chernick WS, Barbero GJ. Composition of tracheobronchial secretions in cystic fibrosis of the pancreas and bronchiectasis. Pediatrics 1959;24:739-45.

5 Potter J, Matthews LW, Lemm J, Spector JS. Composition of pulmonary secretions from patients with and without cystic fibrosis. Am $\mathcal{F}$ Dis Child 1960;100:493-5.

6 Lethem MI, James SL, Marriott C. The role of mucous glycoproteins in the rheologic properties of cystic fibrosis glycoproteins in the rheologic properties of cystic
sputum. Am Rev Respir Dis 1990;142:1053-58.

7 King M. Mucus, mucociliary clearance and coughing. In: Bates DV, ed. Respiratory function in disease. 3rd edn. Philadelphia: Saunders 1989:Chapter 3.

8 Hodson ME, Warner JO. Cystic fibrosis: respiratory problems and their management. Br Med Bull 1992;48:931-48.

9 Stafanger G, Garne S, Howitz P, Morkassel E, Koch C. The clinical effect and the effect on the ciliary motility of oral N-acetylcysteine in patients with cystic fibrosis and primary ciliary dyskinesia. Eur Respir f 1988;1:161-7.

10 Stafanger G, Koch C. N-acetylcysteine in cystic fibrosis and Pseudomonas aeruginosa infection: clinical score, and Pseudomonas aeruginosa infection: clinical score, spirometry and ciliary motility. Eur Respir f 1989;2:234-7.
Ratjen F, Wonne R, Posselt HG, Stover B, Hofmann D, Bender SW. A double blind placebo controlled trial with oral ambroxol and $\mathrm{N}$-acetylcysteine for mucolytic treatment in cystic fibrosis. Eur ₹ Pediatr 1985;144:374-8.

12 Shak S, Capon DJ, Hellmiss R, Marsters SA, Baker CL. Recombinant human DNase I reduces the viscosity of cystic fibrosis sputum. Proc Natl Acad Sci USA 1990;87: 9188-92.

13 Aitken ML, Burke W, McDonald G, Shak S, Montgomery $\mathrm{AB}$, Smith A. Recombinant human DNase inhalation in normal subjects and patients with cystic fibrosis. A phase I study. F Am Med Assoc 1992;267:1947-51.

14 Hubbard RC, McElvaney NG, Birrer P, Shak S, Robinson WW, Jolley C, et al. A preliminary study of aerosolised recombinant human deoxyribonuclease I in the treatmen of cystic fibrosis. N Engl F Med 1992;326:812-5.

15 Ramsey BW, Astley SJ, Aitken ML, Burke W, Colin AA Dorkin HL, et al. Efficacy and safety of short-term administration of aerosolised recombinant human deoxyribonuclease in patients with cystic fibrosis. Am Rev Respir Dis 1993;148:145-51.

16 Ranasinha C, Assoufi B, Shak S, Christiansen D, Fuchs $\mathrm{H}$, Empey D, et al. Efficacy and safety of short-tern administration of aerosolised recombinant human DNase
I in adults with stable stage cystic fibrosis. Lancet 1993; 342:199-202.

17 Fuchs HJ, Borowitz DS, Christiansen DH, Morris EM, Nash ML, Ramsey BW, et al. Effect of aerosolised recombinant human DNase on exacerbations of respiratory comptint human cystic fibrosis. $N$ Engl $₹$ Med 1994;331:637-42.

18 Gibson LE, Cooke RE. A test for concentration of electrolytes in sweat in cystic fibrosis of the pancreas utilising trolytes in sweat in cystic fibrosis of the pancreas utilising
pilocarpine by iontophoresis. Pediatrics 1959;23:545-9.

19 American Thoracic Society. Standardisation of spirometry - 1987 update. Am Rev Respir Dis 1987;136:1285-98.

20 Knudson RJ, Lebowitz MD, Holberg CJ, Burrows B. Changes in the normal maximal expiratory flow-volume curve with growth and ageing. Am Rev Respir Dis 1983; 127:725-34.

21 King $M$, Brock G, Lundell C. Clearance of mucus by stimulated cough. f Appl Physiol 1985;58:1776-82.

$22 \mathrm{King} M$. Role of mucus viscoelasticity in cough clearance. Biorheology 1987;24:589-97.

23 Laube BL, Auci RM, Shields DE, Christiansen D, Fuchs HJ, Rosenstein BJ. A randomised, placebo controlled trial of the effect of recombinant human DNase I (rhDNase) on the deposition homogeneity and mucociliary clearance of radioaerosol in patients with cystic fibrosis. Pediatr of radioaerosol in patients with
Pulmonol 1983;Suppl 9:155-6.

24 Puchelle E, Zahm JM, Polu JM, Sadoul P. Drug effects on viscoelasticity of mucus. Eur $尹$ Respir Dis 1980;61 (Suppl 110):195-208

25 Shih CK, Litt M, Khan MA, Wolf DP. Effect of nondialyzable solids concentration and viscoelasticity on ciliary transport of tracheal mucus. Am Rev Respir Dis 1977; 115:989-95.

26 King M, Gilboa A, Meyer FA, Silberberg A. On the transport of mucus and its rheologic stimulants in ciliated systems. Am Rev Respir Dis 1974;110:740-5.

27 Dulfano MJ, Adler KB. Physical properties of sputum. VII Rheologic properties and mucociliary transport. Am Rev Respir Dis 1975;112:341-7.

28 Shah PL, Scott SF, Marriott C, Knight RA, Hodson ME. A comparison of the rheological and inflammatory activity of cystic fibrosis and bronchiectasis sputum. Eur Respir $\mathcal{F}$ 1994;4(Suppl 18):79s (abstract).

29 Vasconcellos CA, Allen PG, Wohl ME, Drazen JM, Janmey PA, Stössel TP. Reduction in viscosity of cystic fibrosis sputum in vitro by Gelsolin. Science 1994;263:969-71.

30 sputum in vitro by Gelsolin. Science 1994;263:969-71. of F-actin by deoxyribonuclease I. Cell 1976;7:531-42.

31 Lazarides E, Lindberg U. Actin is the naturally occurring inhibitor of deoxyribonuclease I. Proc Natl Acad Sci USA 1974;71:4742-6.

32 Shah PL, Scott SF, Knight RA, Hodson ME. The effects of recombinant human DNase I on neutrophil elastase activity and interleukin-8 levels. Eur Respir $\mathcal{F} 1995$ (in press) 